\title{
Penambahan Keamanan dan Rancang Bangun Sistem Informasi Rekam Medis Electronic (RME)
}

\author{
Estu Sinduningrum ${ }^{1)}$, Ikhwan Anjar Prabowo, Sriyono \\ Program Studi Teknik Informatika, Fakultas Teknik \\ Universitas Muhammadiyah Prof. DR. HAMKA. \\ Jl. Tanah Merdeka No.6, RT.10/RW.3, Rambutan, Kec. Ps. Rebo. \\ Kota Jakarta Timur, Daerah Khusus Ibukota Jakarta, 13830 \\ 1)estu.ningrum@uhamka.ac.id
}

Diterima: 1 September 2019. Disetujui 20 September 2019. Dipublikasikan Nopember 2019

\begin{abstract}
Abstrak - Perkembangan informasi yang terus meningkat, menyebabkan komputerisasi dalam berbagai macam bidang salah satunya adalah bidang kesehatan juga turut bertambah. Hal ini erat kaitannya dengan penggunaan password dalam area komputerisasi. Rawannya manipulasi password dinilai sebagai hal yang perlu dicegah menggunakan data hiding. Salah satu teknik dalam penyembunyian data yaitu kriptografi. Algoritma yang digunakan pada penelitian ini, yaitu algoritma genetika dan fungsi Hash SHA-1. Fungsi Hash SHA-1 adalah untuk mengenkrip string password yang di-input oleh user sehingga menghasilkan chippertext yang sulit ditebak. Perancangan untuk melindungi database pada satu rumah sakit di Jakarta menggunakan algoritma Hash SHA-1 yang ditanamkan di masukan (login) sistem informasi RME untuk melindungi dari akses yang tidak sah dari para peretas. Hasil percobaan dari 35 kali serangan SQL Injection selalu gagal login. Berdasarkan hasil scan menggunakan alat perangkat lunak Acunetix Web Vulnerability Scanner versi 6 maka diperoleh kesimpulan bahwa sistem dinyatakan kuat dan tidak terdeteksi adanya celah ataupun kelemahan.
\end{abstract}

Kata Kunci: kriptografi sha-1; rekam medis elektronik

\section{PENDAHULUAN}

Rekam medis adalah berkas yang berisi identitas, anamnesa, penentuan fisik, laboratorium, diagnosa dan tindakan medis terhadap seorang pasien yang dicatat baik secara tertulis maupun elektronik [1]. Sistem rekam medis dimulai dari pencatatan selama pasien mendapatkan pelayanan medik sampai dengan penyelenggaraan serta pengeluaran berkas rekam medis dan tempat penyimpanan untuk melayani permintaan/ peminjaman oleh pasien atau untuk keperluan lainnya [1]. Beberapa hal penting yang perlu diperhatikan terutama pada keamanan dari sebuah website dan yang menjadi titik kerentanan adalah login dan database.

Sistem login yang menggunakan database sebagai authentication dari username dan password sangat rentan untuk diretas. SQL Injection adalah salah satu teknik serangan yang umum diterapkan oleh para peretas untuk melakukan eksploitasi dari suatu website, dan akibatnya peretas bisa mendapatkan akses tidak sah kedalam sistem dan mengambil data langsung dari database [2].

Konsep RME mirip dengan rekam medis berbasis kertas, yaitu sebagai sarana mendokumentasikan data maupun informasi utama pada sarana pelayanan kesehatan. Kedua format seperti itu juga dapat diartikan sebagai alat komunikasi dan penyimpanan informasi kesehatan milik pasien pada sarana kesehatan. Dengan adanya rekam medis tersebut dapat diketahui mengenai siapa (who), apa (what), kapan (when), dimana (where), mengapa (why), dan bagaimana (how) pelayanan kesehatan diberikan kepada seorang pasien [3].

Kriptografi adalah teknik untuk mengubah suatu pesan masukan agar tidak dapat diketahui isinya, dan membentuk suatu bidang keilmuan yang disebut dengan sebutan ilmu kriptografi. Prinsip dasarnya dari kriptografi adalah menyembunyikan informasi dengan sedemikian rupa agar orang yang berhak menerima informasi tersebut saja yang dapat melihat isi dari informasi yang dikirim tersebut. Seiring dengan kemajuan teknologi, teknik yang dipergunakan untuk mengenkripsi data didalamnya mengandung unsur matematis yang membuat isi dari informasi tersebut semakin sukar untuk diketahui [4]. 
Fungsi hash (hash function atau hash algorithm) adalah suatu cara untuk menghasilkan sebuah digital "fingerprint" kecil dari sembarang data. Fungsi ini memecahkan dan mencampurkan data untuk menghasilkan fingerprint yang sering disebut sebagai nilai hash (hash value) [5]. Nilai hash ini sering direpresentasikan dengan sebuah string pendek dari huruf-huruf dan angka-angka yang kelihatan acak (berbentuk heksadesimal) [5]. Sebuah fungsi hash yang baik adalah suatu fungsi yang tidak (jarang) memiliki output nilai hash yang sama untuk input yang berbeda [5]. Secure Hash Algorithm (SHA) adalah fungsi hash satu arah yang diciptakan oleh institusi yang bernama NIST (National Institute of Standard and Technology). SHA dinyatakan sebagai standar fungsi hash satu arah. SHA dapat dianggap sebagai kelanjutan pendahulunya MD5 dan dapat dikatakan aman karena dibuat sedemikian sehingga secara komputasi tidak memungkinkan menemukan string yang berkaitan dengan message digest yang dihasilkan [5].

SHA1 dikatakan cukup aman karena proses SHA1 dihitung secara infisibel untuk mencari string yang sesuai untuk menghasilkan message digest atau dapat juga digunakan untuk mencari dua string berbeda yang akan menghasilkan message digest yang sama [6].

Berdasarkan data dan pemaparan di atas, maka dibuatlah perlindungan website sistem informasi rekam medis elektronik dengan memanfaatkan fitur security PHP dan secure hash algorithm-1 sebagai algoritma kriptografi untuk mengenkripsi string password.

\section{METODE PENELITIAN}

Metode pengembangan pada penelitian menggunakan metode SDLC dengan model Waterfall. Model Waterfall sering disebut classic lice cycle atau siklus hidup klasik yang menggambarkan penekanan sistematis dan juga berurutan pada pengembangan perangkat lunak yang dimulai dari spesifikasi kebutuhan pengguna kemudian berlanjut melalui tahapan perancangan, Pemodelan, Konstruksi, serta penyerahan sistem kepada para pelanggan dan berakhir dengan perawatan pada perangkat lunak yang telah dibuat [7]. Penjelasan untuk diagram alir penelitian, yaitu:

1. Identifikasi Masalah

Masalah yang terjadi adalah meningkatkan pengamanan security dari web rekam medis elektronik dari berbagai jenis serangan keamanan. Pada suatu rumah sakit di Jakarta, belum adanya sistem kemanan database untuk rekam medis elektronik. Bagaimana merancang sebuah sistem keamanan untuk rekam medis elektronik menggunakan algoritma genetika dan fungsi Hash SHA-1.

\section{Pengumpulan Data}

Metode yang digunakan dalam pengumpulan data adalah studi pustaka, wawancara, dan kuesioner.

3. Perancangan Sistem

Langkah-langkah perancangan sistem diantaranya:

1) Perancangan Database menggunakan bahasa pemrograman MySQL.

2) Perancangan Interface menggunakan bahasa pemrograman PHP.

3) Perancangan Keamanan Sistem dengan penerapan fitur Security PHP.

4. Pengujian

Pengujian keamanan dari penerapan secure hash algorithm-1 adalah dengan menggunakan simulasi serangan SQL Injection. Yang diuji langsung kepada sistem melalui menu login. Tahapan simulasi serangan, dapat dilihat pada Gambar 1.

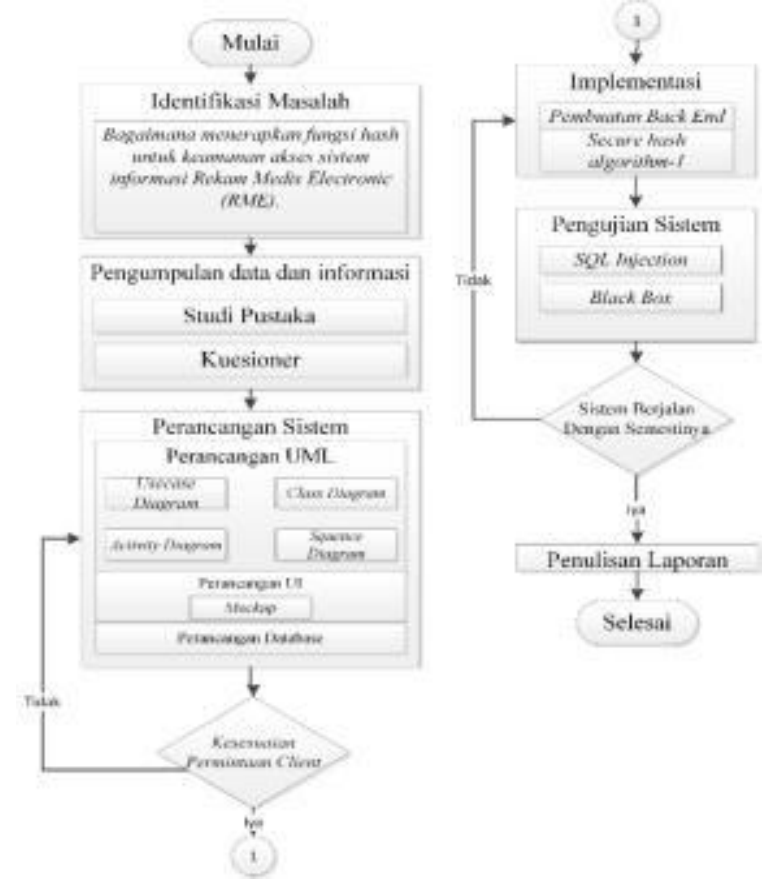

Gambar 1 Diagram Alir Penelitian

Pada Gambar 2 simulasi serangan menggunakan SQL Injection dilakukan dengan memasukkan kode serangan dalam form login untuk mengetahui apakah sistem pengamanan berhasil atau tidak. SQL Injection dicoba pada form login jika kondisinya 'ya' maka dilakukan looping ke form login. Jika tidak berhasil maka berhak masuk ke input login yang harus sesuai dengan data pada database, kemudian disesuaikan dengan data yang ada, jika sesuai maka masuk ke sistem dan sebagai bukti bahwa SQL Injection tidak dapat meretas sistem. 


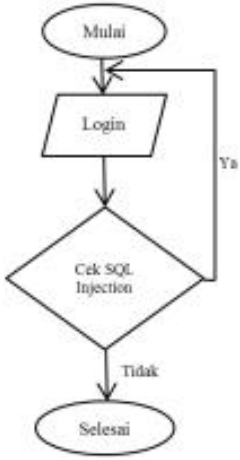

Gambar 2 Tahapan Simulasi Serangan SQL Injection

Pengujian perangkat lunak sistem ini bertujuan sebagai uji coba sebelum aplikasi dirilis kepada pengguna eksternal. Untuk menguji coba apakah aplikasi yang telah dibuat berjalan sesuai dengan output dari fungsi atau fitur yang digunakan oleh pengguna dan pengujian sistem juga bertujuan untuk mencari kesalahan atau error yang terdapat pada aplikasi yang telah dibuat.

Pengujian aplikasi dilakukan menggunakan teknik black box di mana teknik ini berguna untuk menguji coba secara keseluruhan fitur-fiturnya, apakah berfungsi semua atau masih terdapat bug, error, tanpa harus melihat source code-nya jika masih terdapat error maka ulangi ke proses pengkodean sistem, jika tidak ada error maka lanjut ke tahap selanjutnya. Black-Box Testing merupakan pengujian yang berfokus pada spesifikasi fungsional dari perangkat lunak, tester dapat mendefinisikan kumpulan kondisi input dan melakukan pengetesan pada spesifikasi fungsional program [8].

Pengujian hasil enkripsi pada string password yang telah di-input oleh user. Jika seorang user memasukkan kata "admin" pada kolom username dan password, maka kata "admin" pada string password dienkripsi sehingga menjadi sebuah string baru yang acak dan tidak mudah dikenali.

Dapat dilihat pada Tabel 1 bahwa sistem yang telah diterapkan diuji dengan skala likert, dengan data kuesioner yang diberikan kepada pengguna. Skala likert merupakan skala yang digunakan untuk pegukuran yang diperkenalkan oleh likert pada tahun (1932). Skala likert memiliki beberapa jenis pertanyaan yang dikombinasikan sehingga mampu membentuk suatu skor/nilai [9].

TABEL I. HASIL ENKRIPSI STRING PASSWORD DENGAN SHA-1

\begin{tabular}{|c|c|}
\hline Username & Password \\
\hline Admin & $\begin{array}{c}\text { d033e22ae348aec5660fc2140aec35850 } \\
\text { c4da997 }\end{array}$ \\
\hline
\end{tabular}

\section{Pembuatan Laporan}

Pada tahap ini dijelaskan secara keseluruhan mengenai penelitian yang telah dirancang dan diuji.

\section{HASIL DAN PEMBAHASAN}

Perancangan use case diagram ditunjukkan pada Gambar 3. Keamanan ini diletakkan pada bagian login admin.

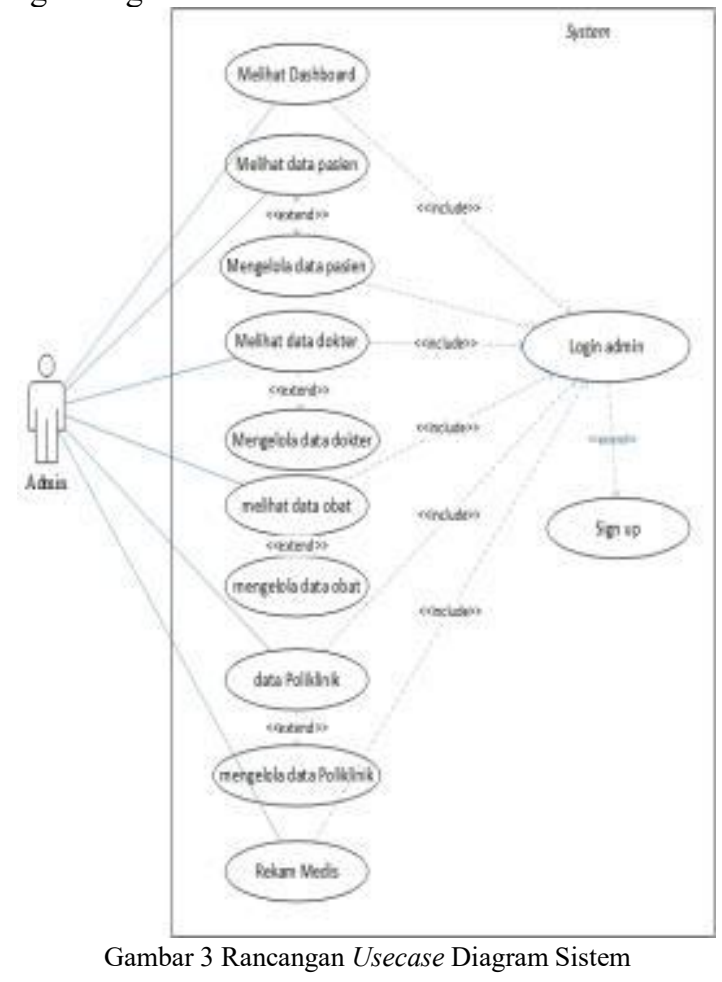

Perancangan class diagram, class diagram menggambarkan struktur status class dalam sistem. Class diagram termasuk ke dalam bagian UML view yaitu logical view dimana class diagram ini mmenjelaskan bagaimana fungsional dari sistem, struktur statis (class, object, relationship) dan kombinasi yang terjadi saat object mengirimkan pesan ke object lain di dalam satu fungsi tertentu. Berikut ini adalah gambaran class diagram pada penelitian ini seperti yang bisa dilihat pada Gambar 4.

Hasil dari rancangan interface dapat dilihat pada Gambar 5 yang merupakan tampilan halaman login dimana terdapat dua jenis pengguna yaitu admin dan perawat. Pada halaman ini user bisa melakukan sign up dengan mengisikan data pada masing masing kolom yang telah disediakan. Gambar 6 merupakan tampilan halaman kelola data pasien yang dapat diakses oleh admin. Admin dapat menambah, menghapus serta meng-edit data pasien pada halaman ini. 


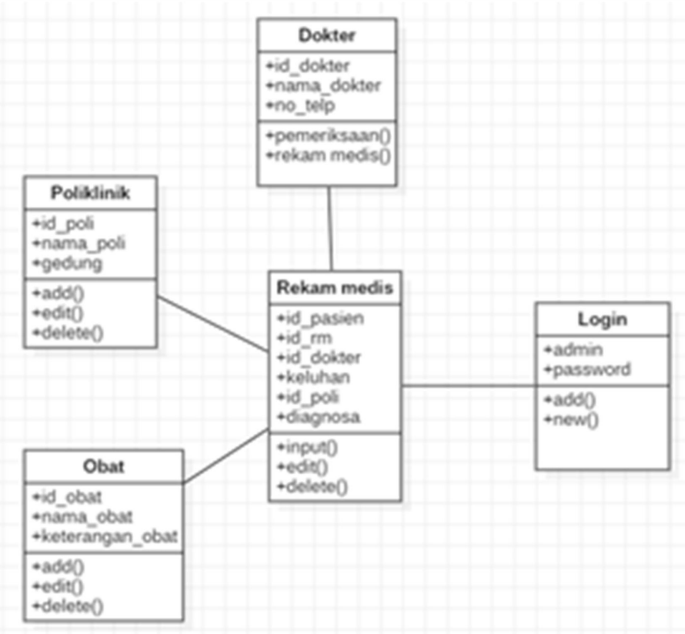

Gambar 4 Perancangan Class Diagram

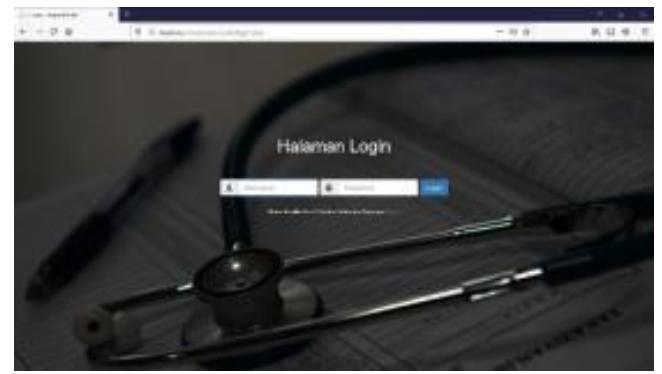

Gambar 5 Tampilan Interface Login

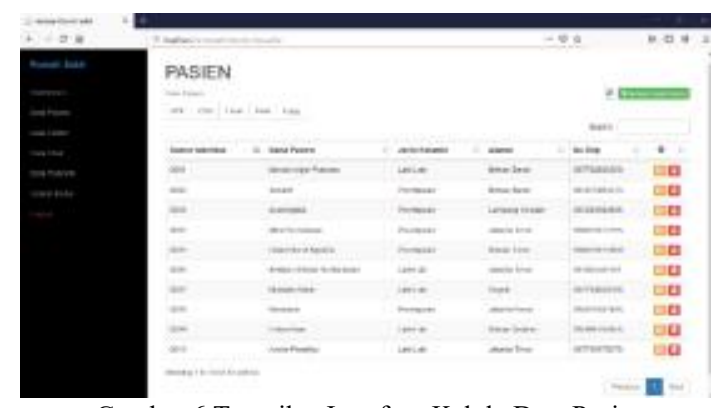

Gambar 6 Tampilan Interface Kelola Data Pasien

Gambar 7, merupakan tampilan halaman kelola data Obat yang hanya dapat diakses oleh admin. Admin dapat menambah, menghapus, serta mengedit data rekam medis pada halaman ini.

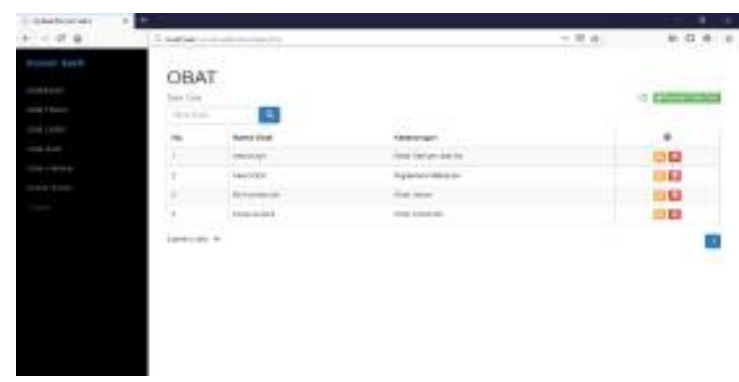

Gambar 7 Tampilan Interface Kelola Data Rekam Medis

\section{Pengujian KeAmanan Sistem}

Pengujian yang dilakukan pada penelitian ini dengan cara memasukkan string password pada halaman login seperti pada Tabel II. Hasil pengujian dapat dilihat pada Gambar 8.

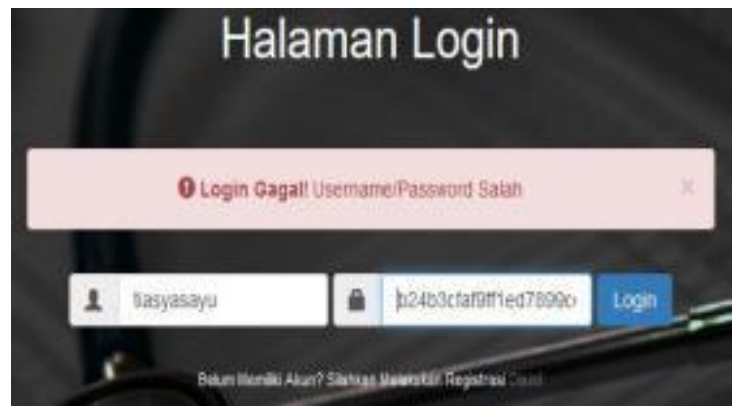

Gambar 8 Hasil pengujian kemanan system

Pengujian SQL Injection, SQL Injection adalah sebuah teknik yang digunakan untuk menyalahgunakan sebuah celah keamanan yang terdapat pada lapisan basis data sebuah aplikasi [2]. Pada penelitian ini telah dilakukan serangan menggunakan SQL Injection namun pada kesempatan ini dilakukan kepada website yang memiliki tingkat keamanan yang baik. Berikut skenario pengujiannya dapat dilihat pada Tabel II.

\begin{tabular}{|c|c|c|}
\hline No & Variable SQL & Dampak Serangan \\
\hline 1 & 'or 1-1\# & Gagal login \\
\hline 2 & "or 1=1- & Gagal login \\
\hline 3 & 'or $1=1-$ & Gagal login \\
\hline 4 & 'or"a'='a'\# & Gagal login \\
\hline 5 & "or"a"="a"\# & Gagal login \\
\hline 6 & Admin’\# & Gagal login \\
\hline 7 & 'or 'x'='x'\# & Gagal login \\
\hline 8 & Admin' or $1=1 \#$ & Gagal login \\
\hline 9 & hi' or 'a'='a'\# & Gagal login \\
\hline 10 & hi”) or (“a"="a & Gagal login \\
\hline 11 & Admin' or $0=0 \#$ & Gagal login \\
\hline 12 & “or"a"="a & Gagal login \\
\hline 13 & “or $0=0 \#$ & Gagal login \\
\hline 14 & $\operatorname{admin}^{\prime}$ or ' $x$ ' ='x & Gagal login \\
\hline 15 & “or "x"="x & Gagal login \\
\hline 16 & ') or ('x'='x & Gagal login \\
\hline 17 & 'or 1=1-- & Gagal login \\
\hline 18 & " or 1=1-- & Gagal login \\
\hline 19 & Or 1=1-- & Gagal login \\
\hline 20 & or $\mathrm{a}=\mathrm{a}--$ & Gagal login \\
\hline 21 & "or "a"="a & Gagal login \\
\hline 22 & hi" or $1=1$-- & Gagal login \\
\hline 23 & admin'-- & Gagal login \\
\hline 24 & 'having 1=1-- & Gagal login \\
\hline 25 & hi' or 'a'='a & Gagal login \\
\hline 26 & hi" or 1=1-- & Gagal login \\
\hline 27 & admin'-- & Gagal login \\
\hline 28 & "or $0=0--$ & Gagal login \\
\hline
\end{tabular}




\begin{tabular}{|l|c|l|}
\hline 29 & admin 'or'a"="a"\# & Gagal login \\
\hline 30 & admin hi' or a'='a'\# & Gagal login \\
\hline 31 & admin'or 1=1\# & Gagal login \\
\hline 32 & admin hi' or a'='a'\# & Gagal login \\
\hline 33 & hi' or 'a'='a\# & Gagal login \\
\hline 34 & hi') or ('a'='a & Gagal login \\
\hline 35 & hi') or ('a"="a\# & Gagal login \\
\hline
\end{tabular}

Gambar 9 merupakan hasil pengujian Threat Sistem dengan bantuan perangkat lunak Acunetix Web Vulnerability Scanner versi 6. Pengujian ini dilakukan dengan menggunakan parameter pengujian Default untuk mengetahui adanya celah dan kelemahan dari Sistem Informasi Rekam Medis Elektronik yang sudah dibangun. Dari Gambar 9 dapat diambil kesimpulan bahwa sistem rekam medis elektronik yang telah dibangun tidak terdapat adanya celah dah kelemahan.

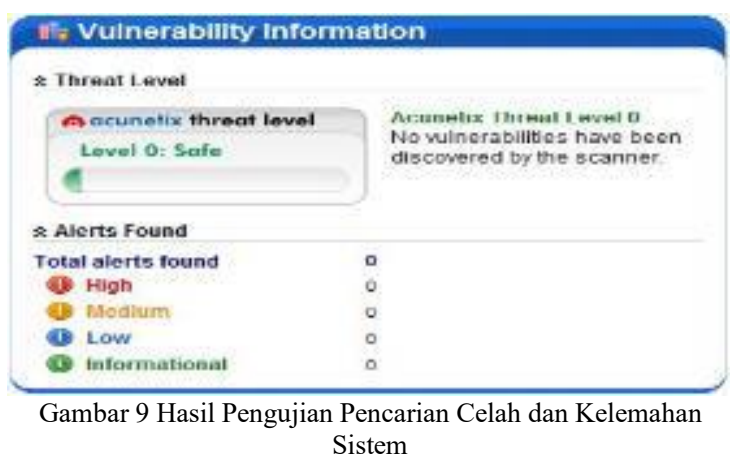

Selanjutnya dilakukan pengujian deskripsi string password melalui website generator. Gambar 10 merupakan hasil pengujian dekripsi pada string password yang sudah ada dalam database dan dijadikan akses untuk login ke dalam website.

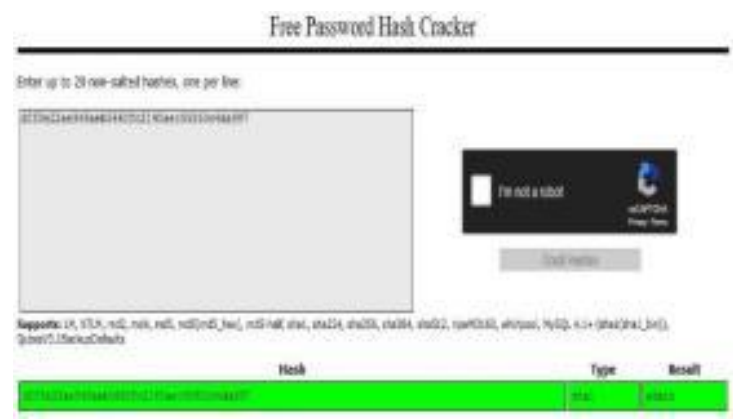

Gambar 10 Hasil Pengujian Dekripsi String Password

Pada Gambar 10 dijelaskan bahwa string enkripsi SHA-1 terhadap kata "admin" masih bisa di dekripsi menggunakan web generator. Hasil yang didapat dari pengujian sistem yang dibangun menggunakan metode black box untuk sistem admin, dapat dilihat pada Tabel III.
TABEL III. HASIL UJI SISTEM ADMIN DENGAN MENGGUNAKAN METODE BLACK BOX

\begin{tabular}{|c|c|c|c|}
\hline No. & Pengujian & Hasil & Keterangan \\
\hline 1 & $\begin{array}{l}\text { Mengisi form } \\
\text { login dengan } \\
\text { mengisi } \\
\text { username dan } \\
\text { password lalu } \\
\text { menekan } \\
\text { tombol login }\end{array}$ & $\begin{array}{lr}\text { Admin } & \text { masuk } \\
\text { kehalaman } & \text { utama } \\
\text { (dashboard) } & \end{array}$ & Sukses \\
\hline 2 & $\begin{array}{l}\text { Memilih menu } \\
\text { Pasien, } \\
\text { Dokter, Obat, } \\
\text { Poliklinik, } \\
\text { Rekam medis. }\end{array}$ & $\begin{array}{l}\text { Pasien : menampilkan } \\
\text { data pasien. } \\
\text { Dokter : menampilkan } \\
\text { data dokter } \\
\text { Obat : menampilkan } \\
\text { data obat. } \\
\text { Poliklinik : } \\
\text { menampilkan halaman } \\
\text { data poiklinik. } \\
\text { Rekam medis : } \\
\text { menampilkan halaman } \\
\text { data rekam medis. }\end{array}$ & Sukses \\
\hline 3 & $\begin{array}{l}\text { Memilih menu } \\
\text { Pasien, } \\
\text { menambah } \\
\text { data, } \\
\text { mengubah } \\
\text { data, } \\
\text { menghapus } \\
\text { data, klik } \\
\text { tombol } \\
\text { kembali, dan } \\
\text { tombol simpan } \\
\text { data. }\end{array}$ & $\begin{array}{l}\text { Memilih menu pasien : } \\
\text { menampilkan halaman } \\
\text { pasien, } \\
\text { Menambah data : } \\
\text { menampilkan halaman } \\
\text { tambah data pasien. } \\
\text { Ubah data : mengubah } \\
\text { data pasien berdasarkan } \\
\text { id yang dipilih } \\
\text { Hapus data : menghapus } \\
\text { data pasien berdasarkan } \\
\text { id yang dipilih } \\
\text { Kembali : kembali ke } \\
\text { halaman data pasien. } \\
\text { Simpan : menyimpan } \\
\text { data }\end{array}$ & Sukses \\
\hline 4 & $\begin{array}{l}\text { Menekan } \\
\text { tombol } \\
\text { PDF,CSV,EXE } \\
\text { L,PRINT,COP } \\
\text { Y }\end{array}$ & $\begin{array}{l}\text { PDF: mendownload data } \\
\text { yang terdapat pada tabel } \\
\text { daftar pasien dalam } \\
\text { format PDF. } \\
\text { CSV : mendownload } \\
\text { data yang terdapat pada } \\
\text { tabel daftar pasien } \\
\text { dalam format Exel } \\
\text { Comma Separated } \\
\text { Values. } \\
\text { Exel : mendownload } \\
\text { data yang terdapat pada } \\
\text { tabel pasien dalam } \\
\text { format Exel } \\
\text { Print : mencetak data } \\
\text { yang terdapat pada tabel } \\
\text { daftar pasien. } \\
\text { Copy: mensalin data } \\
\text { pada daftar pasien ke } \\
\text { Clipboard }\end{array}$ & Sukses \\
\hline 5 & $\begin{array}{l}\text { Memilih menu } \\
\text { Dokter, } \\
\text { menambah } \\
\text { data, } \\
\text { mengubah } \\
\text { data, } \\
\text { menghapus } \\
\text { data, klik } \\
\text { tombol } \\
\text { kembali, dan } \\
\text { tombol simpan } \\
\text { data }\end{array}$ & $\begin{array}{l}\text { Memilih menu dokter : } \\
\text { menampilkan halaman } \\
\text { dokter, } \\
\text { Menambah data : } \\
\text { menampilkan halaman } \\
\text { tambah data dokter. } \\
\text { Ubah data : mengubah } \\
\text { data dokter berdasarkan } \\
\text { id yang dipilih } \\
\text { Hapus data : menghapus } \\
\text { data dokter berdasarkan } \\
\text { id yang dipilih. }\end{array}$ & Sukses \\
\hline
\end{tabular}




\begin{tabular}{|c|c|c|c|}
\hline & & $\begin{array}{l}\text { Kembali : kembali ke } \\
\text { halaman data dokter. } \\
\text { Simpan : menyimpan } \\
\text { data }\end{array}$ & \\
\hline 6 & $\begin{array}{l}\text { Memilih menu } \\
\text { Obat, } \\
\text { menambah, } \\
\text { mengubah, } \\
\text { menghapus } \\
\text { data, dan klik } \\
\text { tombol } \\
\text { kembali, dan } \\
\text { tombol simpan } \\
\text { data. }\end{array}$ & $\begin{array}{l}\text { Memilih menu obat: } \\
\text { menampilkan halaman } \\
\text { obat, } \\
\text { Menambah data : } \\
\text { menampilkan halaman } \\
\text { tambah data obat. } \\
\text { Ubah data : mengubah } \\
\text { data obat berdasarkan id } \\
\text { yang dipilih } \\
\text { Hapus data : menghapus } \\
\text { data obat berdasarkan id } \\
\text { yang dipilih. } \\
\text { Kembali : kembali ke } \\
\text { halaman data obat. } \\
\text { Simpan : menyimpan } \\
\text { data }\end{array}$ & Sukses \\
\hline 7 & $\begin{array}{l}\text { Memilih menu } \\
\text { Poliklinik, } \\
\text { menambah } \\
\text { data, } \\
\text { mengubah } \\
\text { data, } \\
\text { menghapus } \\
\text { data, klik } \\
\text { tombol } \\
\text { kembali, dan } \\
\text { tombol simpan } \\
\text { data. }\end{array}$ & $\begin{array}{l}\text { Memilih menu } \\
\text { poliklinik: menampilkan } \\
\text { halaman poliklinik, } \\
\text { Menambah data : } \\
\text { menampilkan halaman } \\
\text { tambah data poliklinik. } \\
\text { Ubah data : mengubah } \\
\text { data poliklinik } \\
\text { berdasarkan id yang } \\
\text { dipilih } \\
\text { Hapus data: menghapus } \\
\text { data poliklinik } \\
\text { berdasarkan id yang } \\
\text { dipilih. } \\
\text { Kembali : kembali ke } \\
\text { halaman data poliklinik. } \\
\text { Simpan : menyimpan } \\
\text { perubahan }\end{array}$ & Sukses \\
\hline 8 & $\begin{array}{l}\text { Memilih menu } \\
\text { Rekam medis, } \\
\text { menambah } \\
\text { data, mengubah } \\
\text { data, } \\
\text { menghapus } \\
\text { data, klik } \\
\text { tombol } \\
\text { kembali, dan } \\
\text { tombol simpan } \\
\text { data. }\end{array}$ & $\begin{array}{l}\text { Memilih menu Rekam } \\
\text { medis: tampil halaman } \\
\text { Rekam medis, } \\
\text { Menambah data : } \\
\text { menampilkan halaman } \\
\text { tambah data Rekam } \\
\text { medis. } \\
\text { Ubah data : mengubah } \\
\text { data rekam medis } \\
\text { berdasarkan id pasien, id } \\
\text { dokter, id obat yang } \\
\text { dipilih } \\
\text { Hapus data : menghapus } \\
\text { data Rekam medis } \\
\text { berdasarkan id pasien, id } \\
\text { dokter, id obat yang } \\
\text { dipilih. } \\
\text { Kembali : kembali ke } \\
\text { halaman data Rekam } \\
\text { medis. } \\
\text { Simpan : menyimpan } \\
\text { data }\end{array}$ & Sukses \\
\hline
\end{tabular}

Pengujian sistem untuk pengguna dilakukan oleh para relawan. Peneliti telah membagikan kuesioner kepada 25 orang responden, untuk melakukan uji coba terhadap kinerja sistem dan fungsi dari fitur-fitur yang disediakan dalam Sistem Informasi Rekam Medis Elektronik ini. Dengan harapan untuk mengetahui apakah sistem sudah berjalan dengan semestinya. Tabel IV berisi pertanyaan yang diajukan.
TABEL IV. DAFTAR PERTANYAAN KUESIONER

\begin{tabular}{|c|l|}
\hline No & \multicolumn{1}{|c|}{ Kuesioner } \\
\hline 1 & Keamanan data Anda adalah hal yang sangat penting. \\
\hline 2 & $\begin{array}{l}\text { Kriptografi sangat berguna untuk pengamanan data } \\
\text { dalam suatu sistem terkomputerisasi. }\end{array}$ \\
\hline 3 & $\begin{array}{l}\text { Sudah mengetahui sistem informasi rekam medis } \\
\text { elektronik. }\end{array}$ \\
\hline 4 & $\begin{array}{l}\text { Sudah mengetahui bahwa sistem yang telah Anda uji } \\
\text { saat ini adalah salah satu model dari sistem informasi } \\
\text { rekam medis. }\end{array}$ \\
\hline 5 & $\begin{array}{l}\text { Anda tidak menemukan kesulitan dalam } \\
\text { mengoperasikan sistem informasi rekam medis } \\
\text { elektronik tersebut. }\end{array}$ \\
\hline 6 & $\begin{array}{l}\text { Tombol-tombol menu yang tersedia berfungsi dengan } \\
\text { baik. }\end{array}$ \\
\hline
\end{tabular}

Skala likert digunakan untuk menghitung hasil ataupun tanggapan dan penilaian yang didapat dari tahap pengujian sistem. Tabel $\mathrm{V}$ berisi hasil perhitungan kuesioner.

TABEL V. HASIL PERHITUNGAN KUESIONER

\begin{tabular}{|c|c|c|c|c|c|c|c|c|c|c|c|c|c|}
\hline \multirow{2}{*}{ No } & \multicolumn{5}{|c|}{ Skor } & \multirow{2}{*}{$\begin{array}{c}\text { Nilai } \\
\text { Maximum } \\
\text { (N-Max) }\end{array}$} & \multicolumn{5}{|c|}{ Jumlah Skor } & \multirow{2}{*}{ Jumlah } & \multirow{2}{*}{$\begin{array}{c}\text { Persentase } \\
(\%)\end{array}$} \\
\hline & $1 \mid 2$ & 2 & 3 & 4 & 5 & & 1 & 2 & 3 & 4 & 5 & & \\
\hline 1 & 0 & 0 & 0 & 7 & 18 & \multirow{7}{*}{125} & 0 & 0 & 0 & 28 & 90 & 118 & 94.4 \\
\hline 2 & 0 & 0 & 6 & 7 & 12 & & 0 & 0 & 18 & 28 & 60 & 106 & 84.8 \\
\hline 3 & 0 & 3 & 6 & 7 & 9 & & 0 & 6 & 18 & 28 & 45 & 97 & 77.6 \\
\hline 4 & 0 & 0 & 7 & 8 & 10 & & 0 & 02 & 21 & 32 & 50 & 103 & 82.4 \\
\hline 5 & $0 \mid \begin{array}{c}0 \\
0\end{array}$ & 0 & 5 & 7 & 13 & & 0 & 0 & 15 & 28 & 65 & 108 & 86.4 \\
\hline 6 & 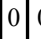 & 0 & 4 & 6 & 15 & & 0 & 0 & 12 & 24 & 75 & 111 & 88.8 \\
\hline $\mathrm{Jml}$ & 0 & 3 & 28 & 42 & 77 & & 0 & 6 & 84 & 168 & 385 & 643 & 514.4 \\
\hline & & & & & & lata-rata & & & & & & & 85.7333333 \\
\hline
\end{tabular}

Nilai Maximal $(\mathrm{N}-\mathrm{Max})=$ Jumlah responden $\mathrm{x}$ Skor

$$
\begin{aligned}
& =25 \times 5 \\
& =125
\end{aligned}
$$

Jumlah Persentase=Total jumlah skor / N-Max * 100 Rata-rata $=$ Jumlah persentase $/$ total skor

$$
\begin{aligned}
& =514 / 6 \\
& =86 \%
\end{aligned}
$$

Pengujian sistem bagi pengguna oleh para relawan dengan membagikan kuesioner berupa sekumpulan pertanyaan mengenai pengujian sistem ini dengan harapan mendapatkan nilai persentase kepuasan dari pengguna mengenai sistem yang telah dibangun. Adapun rincian dari pada masing masing pertanyaan terbilang adalah sebagai berikut:

\section{Pentingnya keamanan data}

Berdasarkan pertanyaan pertama yang diajukan kepada para responden, "Setujukah anda bahwa keamanan data milik pribadi anda adalah hal yang sangat penting?" Sebanyak 18 responden 
menjawab sangat setuju, dan 7 responden menyatakan setuju. Nilai persentase kesuksesan hasil dari pertanyaan pertama adalah 94\% dengan penjelasan sebagai berikut:

a. Sangat setuju memiliki nilai 5 , setuju memiliki nilai 4.

b. Skor tertinggi dalam penelitian ini adalah 125 dari 25 responden, angka 125 merupakan nilai batas tertinggi yang didapat jika seluruh responden memilih sangat setuju seluruhnya $25 * 5=125$.

2. Fungsi Kriptografi

Berdasarkan pertanyaan yang diajukan kepada para responden, "Setujukah anda bahwa penerapan algoritma kriptografi dapat memudahkan anda untuk mengamankan data data pribadi milik anda?" Sebanyak 12 responden menjawab sangat setuju sekali, 7 responden menilai setuju, dan 6 responden menyatakan biasa. Nilai persentase kesuksesan hasil dari pertanyaan kedua adalah $84 \%$ dengan penjelasan sebagai berikut:

a. Sangat setuju memiliki nilai 5 , setuju memiliki nilai 4.

b. Skor tertinggi dalam penelitian ini adalah 125 dari 25 responden, angka 125 merupakan nilai batas tertinggi yang didapat jika seluruh responden memilih sangat setuju seluruhnya $25 * 5=125$.

3. Rekam Medis Elektronik

Berdasarkan pertanyaan yang diajukan kepada pada responden mengenai pengetahuan mengenai Sistem Informasi Rekam Medis Elektronik. Sebanyak 9 orang responden menjawab sangat mengetahui, 7 orang responden menjawab mengetahui, 6 orang responden menjawab hanya pernah mendengar, 3 orang responden menjawab tidak mengetahui. Nilai kesuksesan dari persentase pertanyaan ketiga adalah $77 \%$ dan penjelasannya sebagai berikut:

a. Sangat mengetahui memiliki nilai 5, mengetahui nilai 4, pernah mendengar memiliki nilai 3, dan tidak mengetahui memiliki nilai 2 .

b. Skor tertinggi dalam penelitian ini adalah 125 dari 25 responden, angka 125 merupakan nilai batas tertinggi yang didapat jika seluruh responden memilih sangat setuju seluruhnya $25 * 5=125$.

4. User Experience

Berdasarkan pertanyaan keempat yang diajukan kepada para responden mengenai bagaimana tanggapan para responden ketika pertama kali menggunakan sistem yang dibangun. Sebanyak 10 orang responden menjawab bahwa sistem sangat nyaman digunakan, 8 orang responden menjawab bahwa sistem nyaman digunakan, dan 7 orang responden menjawab bahwa sistem biasa saja. Nilai persentase kesuksesan hasil dari pertanyaan ke empat ini adalah $82 \%$ dengan penjelasan sebagai berikut:

a. Sangat setuju memiliki nilai 5 , setuju memiliki nilai 4, dan biasa memiliki nilai 3

b. Skor tertinggi dalam penelitian ini adalah 125 dari 25 responden, angka 125 merupakan nilai batas tertinggi yang didapat jika seluruh responden memilih sangat setuju seluruhnya $25 * 5=125$.

\section{User Friendly}

Berdasarkan pertanyaan yang diajukan kepada para responden, "Apakah anda masih menemukan kesulitan dalam pengoperasian sistem ini?" Sebanyak 13 responden menjawab sangat mudah digunakan, 7 responden menjawab mudah digunakan, dan 5 responden menyatakan biasa. Nilai persentase kesuksesan hasil dari pertanyaan kelima adalah $86 \%$ dengan penjelasan sebagai berikut:

a. Sangat setuju memiliki nilai 5 , setuju memiliki nilai 4 , dan biasa memiliki nilai 3 .

b. Skor tertinggi dalam penelitian ini adalah 125 dari 25 responden, angka 125 merupakan nilai batas tertinggi yang didapat jika seluruh responden memilih sangat setuju seluruhnya $25 * 5=125$.

6. Fungsional

Berdasarkan pertanyaan yang diajukan kepada para responden, "Apakah ketika saat pengujian, seluruh tombol berfungsi sebagaimana seharusnya?" Sebanyak 15 responden menjawab berfungsi sangat baik, 6 responden menilai berfungsi baik dan 4 menjawab biasa. Nilai persentase kesuksesan hasil dari pertanyaan kelima adalah $88 \%$ dengan penjelasan sebagai berikut:

Berdasarkan pertanyaan yang diajukan kepada para responden, Apakah ketika saat pengujian, seluruh tombol berfungsi sebagaimana seharusnya? Sebanyak 15 responden menjawab berfungsi sangat baik, 6 responden menilai berfungsi baik dan 4 menjawab biasa. Nilai persentase kesuksesan hasil dari pertanyaan kelima adalah $88 \%$ dengan penjelasan sebagai berikut:

a. Sangat setuju memiliki nilai 5 , setuju memiliki nilai 4 , dan biasa memiliki nilai 3 .

b. Skor tertinggi dalam penelitian ini adalah 125 dari 25 responden, angka 125 merupakan nilai batas tertinggi yang didapat jika seluruh responden memilih sangat setuju seluruhnya $25 * 5=125$.

\section{KESIMPULAN DAN SARAN}

Berdasarkan hasil dari percobaan yang dilakukan maka dapat disimpulkan bahwa sistem aman dan mampu mencegah serangan SQL Injection dapat dilihat pada Tabel 1. Hasil percobaan dari 35 kali serangan selalu gagal login. Berdasarkan hasil scan pada Gambar 9 menggunakan alat bantuan 
perangkat lunak Acunetix Web Vulnerability Scanner versi 6 mengenai celah dan kelemahan dari sistem. Sistem dinyatakan kuat dan tidak terdeteksi adanya celah ataupun kelemahan. Telah dibuat Sistem Informasi Rekam Medis Elektronik yang telah menerapkan fungsi enkripsi pada string password menggunakan Security Hash Algorithm-1. Hasil pengujian didapatkan rata-rata $86 \%$, yang berarti pemanfaatan security dengan Security Hash Algorithm-1.

Saran untuk perbaikan dan pengembangan penelitian selanjutnya adalah antara lain: melakukan penambahan kombinasi algoritma lain agar proses dekripsi melalui website generator dapat diminimalisir. Menambahkan fitur keamanan penunjang untuk membangkitkan kode OTP. Menerapkan Sistem Informasi Rekam Medis Elektronik pada sistem operasi lain seperti $i O S$, Windows Phone, Android (Mobile).

\section{REFERENSI}

[1] R. Silalahi and E. J. Sinaga, "Perencanaan Implementasi Rekam Medis Elektronik Dalam Pengelolaan Unit Rekam Medis Klinik Pratama Romana," J. Manaj. Inf. Kesehat. Indones., vol. 7, no. 1, p. 22, 2019.

[2] S. Lika, R. Dwi, P. Halim, and I. Verdian, "ANALISA SERANGAN SQL INJEKSI MENGGUNAKAN SQLMAP Implementation," J. Sist. dan Teknol. Inf., vol. 4, no. 2, pp. $88-94,2018$
[3] R. Dwi., "Identifikasi ketidaklengkapan rekam medis pasien rawat inap Rumah Sakit Muhammadiyah Lamongan.," J. Adm. Kesehat. Indones., vol. 1:2, pp. 192 199, 2013.

[4] F. N. Pabokory, I. F. Astuti, and A. H. Kridalaksana, "Implementasi Kriptografi Pengamanan Data Pada Pesan Teks, Isi File Dokumen, Dan File Dokumen Menggunakan Algoritma Advanced Encryption Standard," Inform. Mulawarman J. Ilm. Ilmu Komput., vol. 10, no. 1, p. 20, 2016.

[5] K. Aryasa and Y. T. Paulus, "Implementasi Secure Hash Algorithm-1 Untuk Pengamanan Data Dalam Library Pada Pemrograman Java," Creat. Inf. Technol. J., vol. 1, no. 1, p. 57, 2015.

[6] M. S. Ramadhan, P. F. Ariyani, T. Informatika, F. T. Informasi, and U. B. Luhur, "PENINGKATAN KEAMANAN LOGIN WEBSITE DENGAN IMPLEMENTASI ONE TIME PASSWORD MENGGUNAKAN ALGORITMA SHA1 DAN MD5 BERBASIS MOBILE," vol. 1, no. 2, pp. 689-696.

[7] S. Maesaroh, D. R. Ramlan, and Arsul, "Rancang Bangun Sistem Informasi Kepegawaian (Simpeg) Dengan Sdlc Metode Waterfall Studi Kasus Di Kantor Bkpld Kabupaten Tasikmalaya," Tedc, vol. 11, no. 2, pp. 197-202, 2017.

[8] M. S. Mustaqbal, R. F. Firdaus, and H. Rahmadi, "PENGUJIAN APLIKASI MENGGUNAKAN BLACK BOX TESTING BOUNDARY VALUE ANALYSIS (Studi Kasus : Aplikasi Prediksi Kelulusan SNMPTN)," vol. I, no. 3, pp. 31-36, 2015.

[9] S. Syofian, T. Setiyaningsih, and N. Syamsiah, "Otomatisasi metode penelitian skala likert berbasis web," Tinf-023, no. November, pp. 1-8, 2015. 